\title{
PEMBELAJARAN MATEMATIKA BERHITUNG PERKALIAN DENGAN METODE JARIMAJIG
}

\author{
Oleh: Kristi Liani Purwanti, S.Si, M.Pd ${ }^{1}$
}

\begin{abstract}
Abstrak
Pembelajaran matematika adalah proses pemberian pengalaman belajar kepada siswa melalui serangkaian kegiatan yang terencana sehingga siswa memperoleh kompetensi tentang bahan matematika yang dipelajari. Salah satu komponen yang menentukan ketercapaian kompetensi adalah penggunaan strategi pembelajaran, yang sesuai dengan (1) topik yang sedang dibicarakan, (2) tingkat perkembangan intelektual siswa, (3) prinsip dan teori belajar, (4) keterlibatan aktif siswa, (5) keterkaitan dengan kehidupan siswa sehari-hari, dan (6) pengembangan dan pemahaman penalaran matematis. Otak merupakan bagian sentral dari fungsi dasar vital pada manusia. Otak kanan adalah otak yang berada disebelah kanan dalam posisi anatomis (frontal). Berhitung perkalian dengan otak kanan salah satunya adalah metode jarimagic dimana perantara untuk menghitung perkalian menggunakan jari-jari tangan. Kemampuan mengingat, menalar, dan merasakan perbedaan sikap atau perlakuan orang lain juga berkembang dengan pesat. Anak lebih sensitif, cerdas, dan aktif secara fisik mupun psikologis. Belajar matematika dengan otak kanan lebih menarik, sebab yang selalu digunakan selama ini dengan otak kiri saja. Jika ada keseimbangan antara otak kanan dan otak kiri pembelajaran menjadi luar biasa.
\end{abstract}

Kata kunci: otak kanan, metode jarimagic, pembelajaran matematika

\footnotetext{
${ }^{1}$ Dosen Fakultas Tarbiyah
} 


\section{Pendahuluan}

Matematika sebagai pokok dari segala ilmu (mother of science), sudah menjadi keharusan bahwa matematika harus dipelajari sejak dini. Pembelajaran matematika adalah proses pemberian pengalaman belajar kepada siswa melalui serangkaian kegiatan yang terencana sehingga siswa memperoleh kompetensi tentang bahan matematika yang dipelajari. ${ }^{2}$ Kemampuan matematika setiap anak berbeda-beda, terutama kemampuan dalam berhitung. Pelajaran matematika merupakan pelajaran yang sangat menarik dan menyenangkan, apabila cara pengajaran dan pembelajarannya menarik, kreatif dan menyenangkan/fun. Maka perlu terobosan baru dalam pengajaran dan pembelajarannya, salah satunya menerapkan metode jarimagic. Metode jarimagic memiliki sepuluh keunggulan yaitu simple, smart, standard, safe, real, quick, practical, effective, fun, dan award. $^{3}$ Metode jarimagic ini adalah salah satu berhitung dasyat dengan otak kanan. Untuk membantu siswa MI/SD dalam berhitung perrkalian yang mudah sehingga disarankan untuk menggunakan metode jarimagic.

\section{Pembahasan}

\section{Pertumbuhan dan Perkembangan Anak}

Dalam masa pertumbuhannya, tiap anak mengalami dan melalui masa-masa pembelajaran yang tidak selalu sama. Menurut penelitian para ahli pendidikan' pembentukan potensi belajar tiap orang terjadi dengan tahapan sebagai berikut: (1) $50 \%$ pada usia 0-4 tahun; (2) 40\% pada usia 4-8 tahun; (3) 30\% pada usia 8-18 tahun; (4) $20 \%$ pada usia 18-25 tahun; dan $10 \%$ pada usia 25-50 tahun. ${ }^{4}$ Persentase pembelajaran maksimal dihitung sebesar 50\% karena persentase lebih besar dari itu dianggap sebagai pembelajaran yang memaksa. Artinya hal tersebut tidak bersifat alami lagi. Bila dilihat dari persentase tersebut, tampaknya, kemampuan belajar manusia mengalami persentase penurunan, dalam arti: "semakin tua, maka kemampuan belajar seseorang semakin menurun".

Misalnya, kemampuan mengingat bayi umur 0-4 tahun,menurut penelitian, lebih besar daripada anak umur 4-8 tahun, meskipun tidak dapat mengungkapkan secara nyata. Daya ingat bayi lebih luas dan besar karena mencakup semua hal yang

\footnotetext{
${ }^{2}$ Muhsetyo, Gatot. 2009. Pembelajaran Matematika SD. Jakarta: Universitas Terbuka.

${ }^{3}$ Auliya, M. Fajar. 2012. Jarimagic Perkalian dan Pmbagian. Jakarta: PT. Buku Seru

${ }^{4}$ Muliawan, Jasa Ungguh. 2009. Tips Jitu Memilih Minan Positif dan Kreatif untuk Anak Anda. Yogjakarta: DIVA Press.
} 
berhubungan kontrol indra, sentuhan fisik, pengenalan bentuk, suara, sampai pada pembedaan wajah orang-orang sekitar di sekelilingnya. Dalam hal ini, penelitian tersebut diformulasikan pada kapasitas rasio ingatan atau memori. Dalam dunia pendidikan, ini lebih dikenal dengan istilah kemampuan menghafal/ hafalan. Ini berarti skala tersebut tidak berlaku menyeluruh. Karena, pada kenyataanya, kemampuan nalar (berpikir) yang tidak selalu identik dengan hafalan dalam diri manusia dari tahun ke tahun mengalami peningkatan. Contohnya kemampuan berpikir logis.

\section{Teori Belajar}

Pembelajaran matematika adalah proses pemberian pengalaman belajar kepada siswa melalui serangkaian kegiatan yang terencana sehingga siswa memperoleh kompetensi tentang bahan matematika yang dipelajari. Salah satu komponen yang menentukan ketercapaian kompetensi adalah penggunaan strategi pembelajaran, yang sesuai dengan (1) topik yang sedang dibicarakan, (2) tingkat perkembangan intelektual siswa, (3) prinsip dan teori belajar, (4) keterlibatan aktif siswa, (5) keterkaitan dengan kehidupan siswa sehari-hari, dan (6) pengembangan dan pemahaman penalaran matematis. Teori perkembangan intelektual Piaget, berpendapat bahwa proses berpikir manusia sebagai suatu perkembangan yang bertahap dari berpikir intelektual konkret ke abstrak berurutan melalui empat periode. Urutan periode itu tetap bagi setiap orang, namun usia atau kronologis pada setiap orang yang memasuki setiap periode berpikir yang lebih tinggi berbeda-beda tergantung kepada masing-masing individu. Ada empat tahap adalah sebagai berikut: (1) tahap sensori-motor (0-2 tahun); (2) tahap pra-operasional (2-7 tahun); (3) tahap konkrit operasional (7-12 tahun); (4) tahap formal operasional (12 dewasa). ${ }^{5}$ Siswa MI/SD masuk dalam tahap pra-operasional yaitu suatu proses berpikir atau logik, dan merupakan aktivitas mental, bukan aktivitas sensori motor. Pada periode ini anak di dalam berpikirnya tidak didasarkan kepada keputusan yang logis melainkan didasarkan kepada keputusan yang dapat dilihat seketika. Pada tahap ini, anak mengalami masa-masa puncak pembelajaran. Kemampuan mengingat, menalar, dan merasakan perbedaan sikap atau perlakuan orang lain juga berkembang dengan pesat. Anak lebih sensitif, cerdas, dan aktif secara fisik amupun psikologis. Yang diperlukan pada masa-masa ini adalah pembelajaran yang bersifat keseimbangan menyeluruh secara terus menerus dan terpadu. Antara intelektual

\footnotetext{
${ }^{5}$ Muhsetyo, Gatot. 2009. Pembelajaran Matematika SD. Jakarta: Universitas Terbuka.
} 
dengan emosional, moral dengan nalar, fisik dengan psikologis, teori dengan praktik, dan seterusnya.

Belajar matematika adalah belajar mengenai konsep-konsep dan struktur-struktur matematika yang terdapat di dalam materi yang dipelajari, serta mencari hubungan antara konsep-konsep dan struktur-struktur matematika itu. Ada 3 tahap dalam proses belajar menurut Bruner yaitu (1) model tahap enaktif, dalam tahap ini penyajian yang dilakukan melalui tindakan siswa secara langsung terlibat dalam memanipulasi (mengotak-atik) objek. (2) model tahap ikonik, dalam tahap ini kegiatan penyajian dilakukan berdasarkan pada pikiran internal dimana pengetahuan disajikan melalui serangkaian gambar-gambar atau grafik yang dilakukan siswa, berhubungan dengan mental yang merupakan gambaran dari objek-objek yang dimanipulasinya. (3) model tahap simbolis, dalam tahap ini bahasa adalah pola dasar simbolik, siswa memanipulasi simbol-simbol atau lambang-lambang objek tertentu. Siswa tidak lagi terikat dengan objek-objek seperti pada tahap sebelumnya. Siswa pada tahap ini sudah mampu menggunakan notasi tanpa ketergantungan terhadap objek riil. Pada tahap simbolik ini, pembelajaran direpresentasikan dalam bentuk simbol-simbol abstrak yaitu simbolsimbol arbiter yang dipakai berdasarkan kesepakatan orang-orang dalam bidang yang bersangkutan, baik simbol-simbol verbal lambang-lambang matematika, maupun lambang-lambang abstrak yang lain.

\section{Otak Kanan}

Otak manusia adalah struktur lunak yang dilindungi oleh cangkang berupa tengkorak. Berdasarkan letaknya secara simetris, otak dibagi menjadi otak kanan (hemisfer kanan) dan otak kiri (hemisfer kiri). Otak merupakan bagian sentral dari fungsi dasar vital pada manusia. Kerusakan pada otak, akan sangat mengganggu aktivitas bagi penderitanya. ${ }^{6}$

\footnotetext{
${ }^{6}$ http://dammar-asihan.blogspot.com/2013/03/perbedaan-fungsi-otak-kanan-danotak.html\#
} 


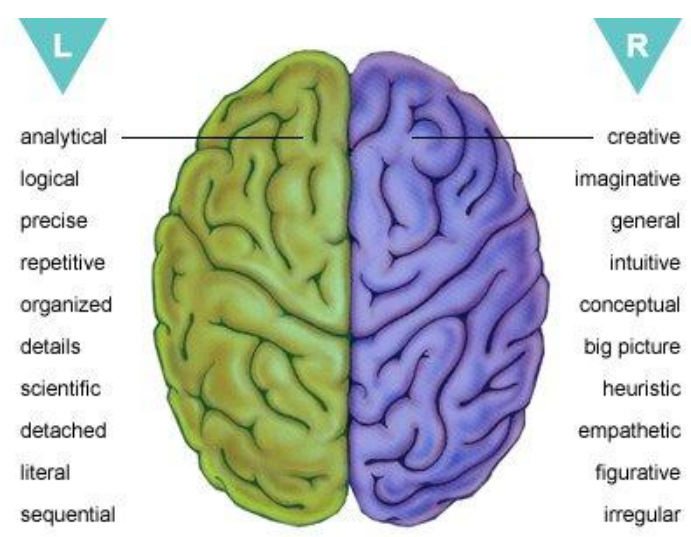

Otak kanan adalah otak yang berada disebelah kanan dalam posisi anatomis (frontal). Fungsi otak kanan adalah sebagai berikut:

- Perkembangan emosi (emotional quotient (EQ))

- Hubungan antar manusia (sosialisasi)

- Fungsi Komunikasi (perkembangan bahasa non verbal)

- Perkembangan intuitif

- Seni (menari, melukis, menyanyi dan lain-lain)

- Mengandalikan ekspresi manusia

- Pusat khayalan dan kreativitas

- Berpikir lateral dan tidak terstruktur

- Tidak memikirkan hal-hal secara detail

- Cara kerjanya long term memory (memory jangka panjang)

- Lebih ahli dalam menentukan ruang/tempat dan warna

Bila terjadi kerusakan pada area otak kanan yang terganggu adalah area kemampuan visual dan emosi

Demikian dikatakan Arman Andi Amirullah, Direktorat Pembinaan TK \& SD Departemen Pendidikan Nasional Pusat, dalam Seminar Sehari "Mengungkap Rahasia Otak Kanan Anak" di aula Kelurahan Cipinang Cempedak, Jakarta Timur, Rabu (19/1/2011) lalu. Pembicara lain dalam seminar ini adalah Dra Dhauharah Bawazir, Psi, M.Pd, praktisi pendidikan yang juga seorang dosen psikologi dan bimbingan konseling Universitas Negeri Jakarta (UNJ). Lebih jauh Arman menjelaskan, Islam adalah agama merangsang otak kanan manusia menjadi berfungsi. Betapa tidak, ketika kita mencoba memahami bagaimana pergantian malam dan siang terjadi, seperti dijelaskan dalam Al Qur'an, tentu diperlukan daya imajinasi untuk bisa merasakan kebesaran Tuhan dalam menciptakan alam semesta, menumbuhkan aneka tumbuhan, dan bagaimana Sang 
Khaliq menurunkan hujan. "Sesungguhnya dalam penciptaan langit dan bumi, dan silih bergantinya malam dan siang terdapat tanda-tanda bagi orang-orang yang berakal, yaitu orang-orang yang mengingat Allah sambil berdiri atau duduk atau dalam keadaan berbaring dan mereka memikirkan tentang penciptaan langit dan bumi seraya berkata: "Ya Tuhan kami, tiadalah Engkau menciptakan ini dengan sia-sia. Maha Suci Engkau, maka peliharalah kami dari siksa neraka" (Qs. Ali Imran 190-191). "Tanpa bantuan imajinasi (otak kanan), kita tidak sanggup melihat dan merasakan langsung tanda-tanda yang dimaksud, dan tidak sanggup memikirkan penciptaan langit dan bumi," ungkap Arman. $^{7}$

Bahkan dalam hadits Nabi dikatakan: "Sembahlah Tuhan-Mu seakan-akan engkau melihatnya, dan apabila kamu tidak sanggup melihat-Nya, maka yakinlah bahwa Allah melihat kamu." Sangat jelas dalam hadits ini, perintah untuk seolah-olah melihat Allah dalam shalat adalah pekerjaan imajinasi atau kemampuan "membayangkan." Seperti kita ketahui, sepertiga dari ayat-ayat suci Al Quran adalah bercerita tentang kisah jaman dahulu dan banyak menggunakan kata perumpamaan: seakan-akan, seperti, yang tentunya membutuhkan daya imajinasi yang kuat. "Tahukah Anda kalau daya imaninasi adalah tanggungjawab otak kanan?" kata Arman.

\section{Berhitung Perkalian dengan Otak Kanan}

Kemampuan matematika siswa MI/SD sangat penting sebab pembelajaran yang dialami anak MI/SD merupakan pondasi dari semua tingkatan jenjang sekolah. Sekolah dasar mempunyai peran penting dalam pembelajaran. Pembelajaran matematika dengan menggunakan jarimajig sebagai berikut ini.

Perkalian ada beberapa macam yang akan dibahasa yaitu

\section{Perkalian kombinasi 1-5}

Kombinasi tangan kiri

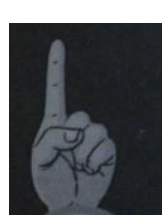

1

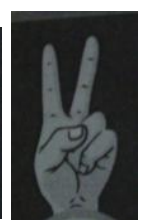

23

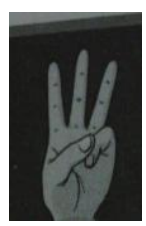

3

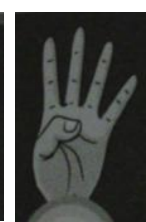

$4 \quad 5$

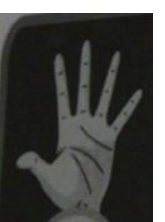

Kombinasi tangan kanan

\footnotetext{
${ }^{7}$ http://oediku.wordpress.com/2010/01/09/keuntungan-pengguna-otak-kanan-
} berbanggalah-jika-engkau-bukan-pengguna-otak-kiri/ ( 25 April 2013) 


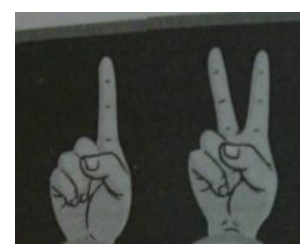

12

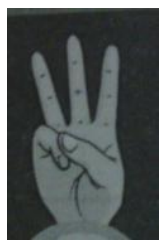

3

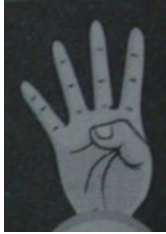

4

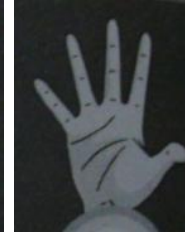

5

TS adalah banyaknaya titik persilangan jari kanan dan jari kiri yang terbuka Contoh:

$3 \times 1=$ ?

"buka 3 jari kiri dan buka 1 jari kanan lalu silangkan dan hitung titik persilangan jarinya"

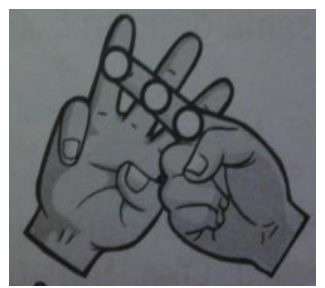

Banyaknya titik persilangan jari ada 3

sehingga $3 \times 1=3$

\section{Perkalian kombinasi 5-10}

Kombinasi tangan kiri

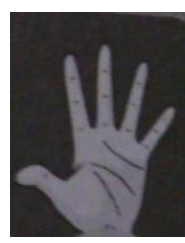

5

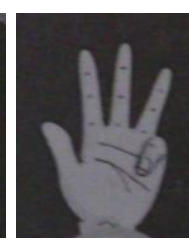

6

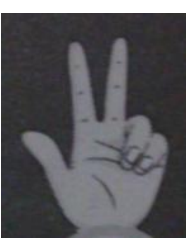

7

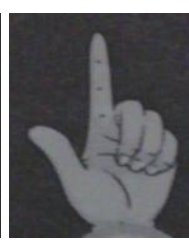

8

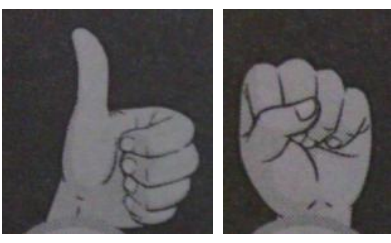

9

Kombinasi tangan kanan

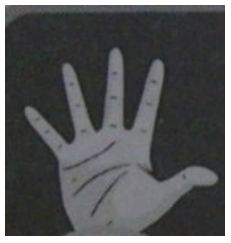

5

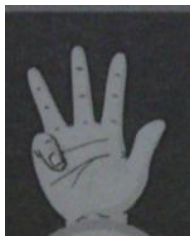

6

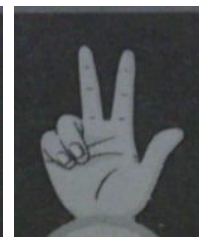

7

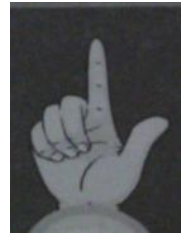

8

9

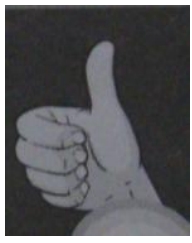

10

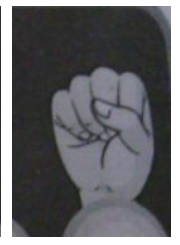

\section{0}

Kali 5-10=(T) _ B

$\mathrm{T}$ adalah jumlah jari yang telungkup 
$\mathrm{B}$ adalah perkalian yang terbuka

Contoh

$7 \times 5=?$

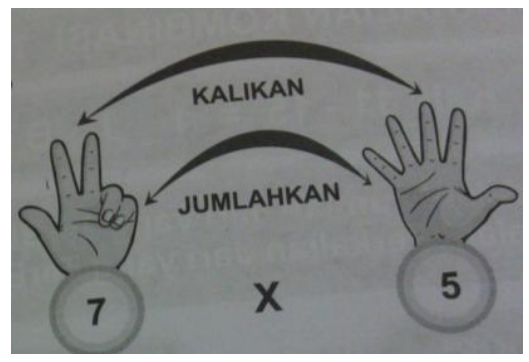

“jari kanan dan kiri yang terbuka kalikan, jari kanan dan kiri yang telungkup jumlahkan, $\mathrm{T}=$ jumlah jari telungkupnya $=2+0=2$

$\mathrm{B}=$ perkalian jari terbukanya $=3 \times 5=15$

Sehingga 7 × $5=(\mathrm{T})_{-} \mathrm{B}$

$$
=2 \_15=(2+1) \_5=35
$$

\section{Perkalian kombinasi 11-15}

Kombinasi tangan kiri
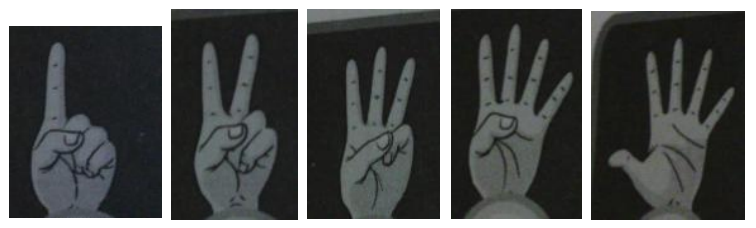

11

12

13

14

15

Kombinasi tangan kanan
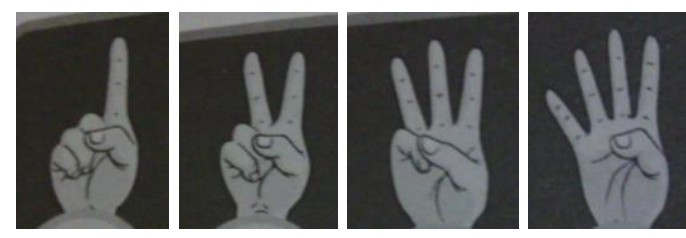

11

12

13

14

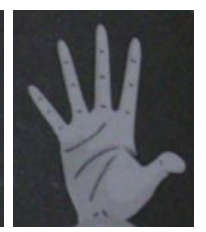

15

Kali 11-15 = 1_J_B

$\mathrm{J}$ adalah jumlah jari yang terbuka

$\mathrm{B}$ adalah perkalian jari yang terbuka

Contoh

$14 \times 12=$ ? 


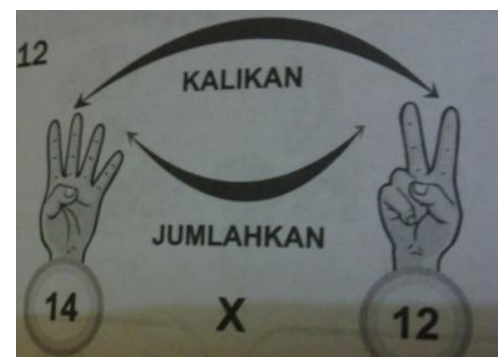

Jari kanan dan kiri terbuka kalikan, jari kanan dan kiri yang terbuka dijumlahkan

$\mathrm{J}=$ jumlah jari yang terbuka $=4+2=6$

$\mathrm{B}=$ perkalian jari yang terbuka $=4 \times 2=8$

Sehingga : 14 x $12=1$ J_B

$$
\text { =1_6_8 = } 168
$$

\section{Perkalian kombinasi 15-20}

Kombinasi tangan kiri

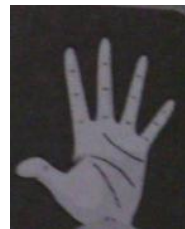

15

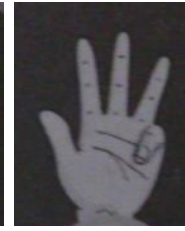

16

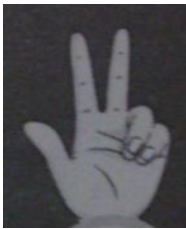

17

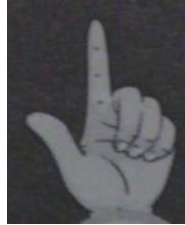

18

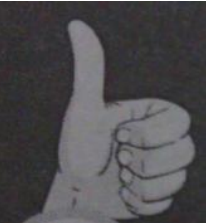

19

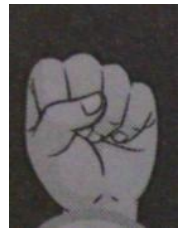

20

Kombinasi tangan kanan

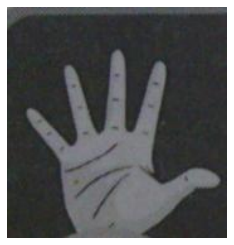

15

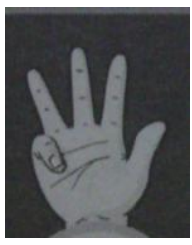

16

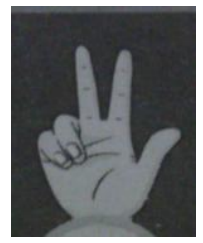

17

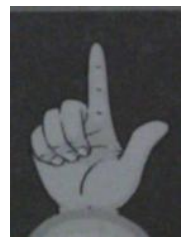

18

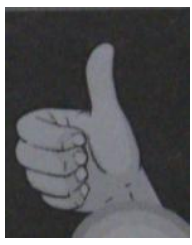

19

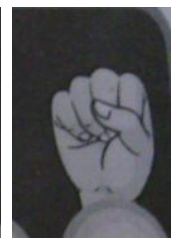

20

Kali $15-20=(20+2 \mathrm{~T})_{-}$B

$\mathrm{T}$ adalah jumlah jari yang telungkup

$\mathrm{B}$ adalah perkalian jari yang terbuka

Contoh

$17 \times 15=$ ?

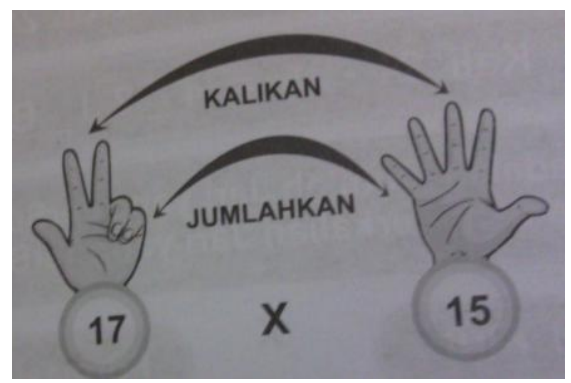


Jari kanan dan kiri terbuka kalikan, jari kanan dan kiri yang telungkup jumlahkan

$\mathrm{T}=$ jumlah jari yang telungkupnya $\quad=2+0=2$

$\mathrm{B}=$ perkalian jari yang terbuka $\quad=3 \times 5=15$

Sehingga : 17 x $15=(20+2 \mathrm{~T}) \_B$

$$
\begin{aligned}
& =(20+2 \times 2) \_15 \\
& =(20+4) \_15 \\
& =24 \_15 \\
& =(24+1) \_5 \\
& =255
\end{aligned}
$$

\section{Perkalian kombinasi 21-25}

Kombinasi tangan kiri
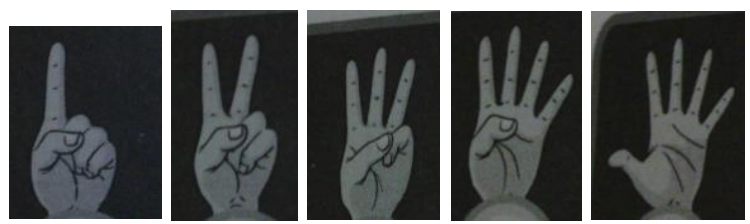

21

22

23

24

25

Kombinasi tangan kanan

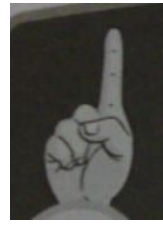

21

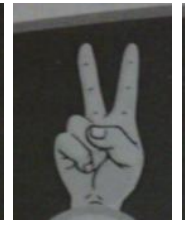

22

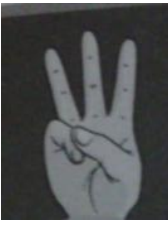

23

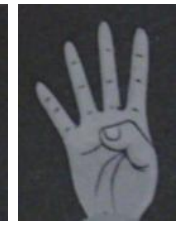

24

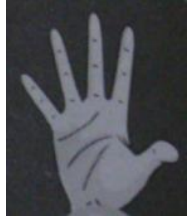

25

Kali 21-25 = 4_2J _ B

$\mathrm{J}$ adalah jumlah jari yang terbuka

$\mathrm{B}$ adalah perkalian jari yang terbuka

Contoh

$24 \times 22=?$

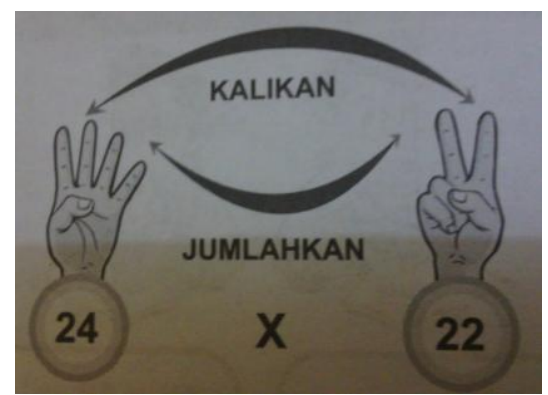

Jari kanan dan kiri terbuka kalikan, jari kanan dan kiri yang terbuka dijumlahkan 
$\mathrm{J}=$ jumlah jari yang terbuka $\quad=4+2=6$

$\mathrm{B}=$ perkalian jari yang terbuka $=4 \times 2=8$

Sehingga : 24 x $22=4$ _2J_B

$$
\begin{aligned}
& =4 \_(2 \times 6) \_8 \\
& =4 \_12 \_8 \\
& =(4+1) \_2 \_8 \\
& =528
\end{aligned}
$$

\section{Perkalian kombinasi $25-30$}

Kombinasi tangan kiri

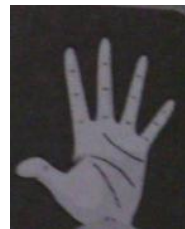

25

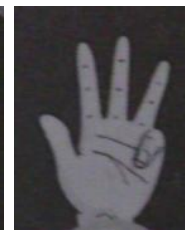

26

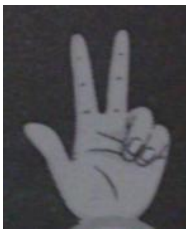

27

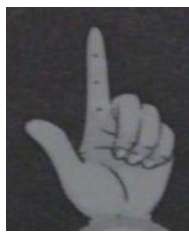

28

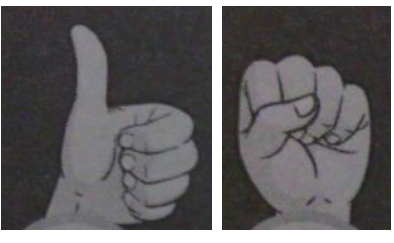

29
30

Kombinasi tangan kanan

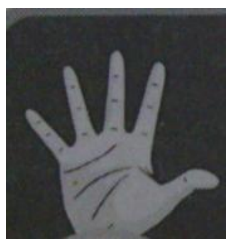

25

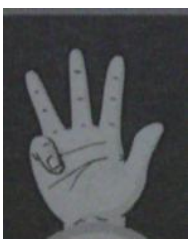

26

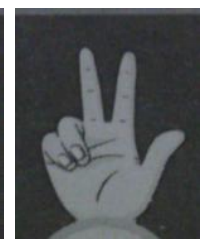

27

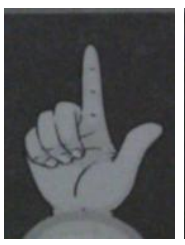

28

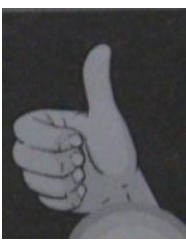

29

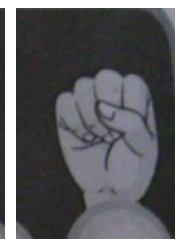

30

Kali $25-30=(60+3 T)_{-} B$

$\mathrm{T}$ adalah jumlah jari yang telungkup

$\mathrm{B}$ adalah perkalian jari yang terbuka

Contoh

$27 \times 25=?$

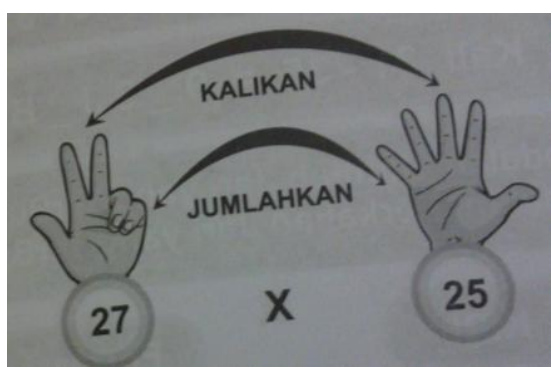

Jari kanan dan kiri terbuka kalikan, jari kanan dan kiri yang telungkup jumlahkan $\mathrm{T}=$ jumlah jari yang telungkupnya $\quad=2+0=2$ 
$\mathrm{B}=$ perkalian jari yang terbuka $\quad=3 \times 5=15$

Sehingga : 27 × $25=(60+3 T) \_B$

$$
\begin{aligned}
& =(60+3 \times 2) \_15 \\
& =(60+6) \_15 \\
& =66 \_15 \\
& =(66+1) \_5 \\
& =675
\end{aligned}
$$

\section{Perkalian kombinasi 31-35}

Kombinasi tangan kiri

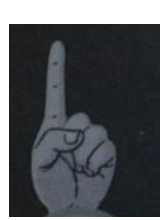

31

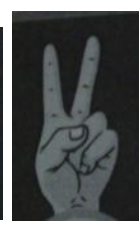

$32 \quad 33$

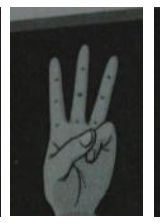

$33 \quad 34$

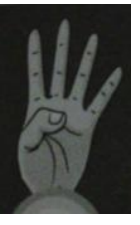

$34 \quad 35$

Kombinasi tangan kanan

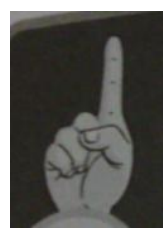

31

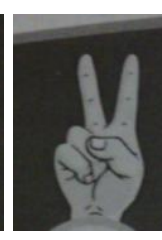

32

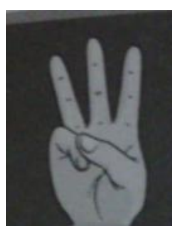

33

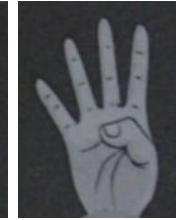

34

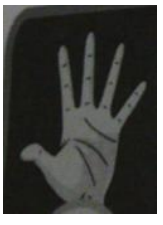

Kali 31-35 =9_3J_B

$\mathrm{J}$ adalah jumlah jari yang terbuka

$\mathrm{B}$ adalah perkalian jari yang terbuka

Contoh

$34 \times 32=?$

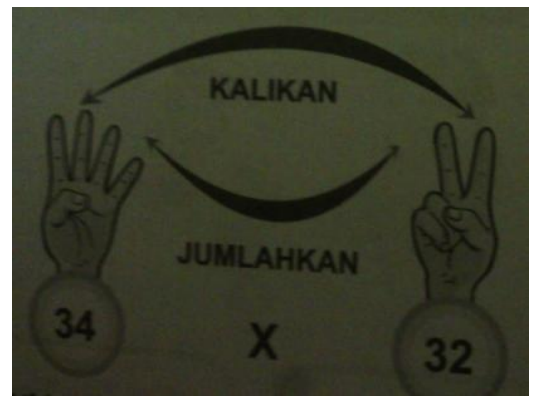

Jari kanan dan kiri terbuka kalikan, jari kanan dan kiri yang terbuka dijumlahkan

$\mathrm{J}=$ jumlah jari yang terbuka $=4+2=6$

$\mathrm{B}=$ perkalian jari yang terbuka $=4 \times 2=8$ 
Sehingga : 34 x $32=9 \_3 J \_B$

$$
\begin{aligned}
& =9 \_(3 \times 6) \_8 \\
& =9 \_18 \_8 \\
& =(9+1) \_8 \_8 \\
& =1088
\end{aligned}
$$

\section{Perkalian kombinasi $\mathbf{3 5 - 4 0}$}

Kombinasi tangan kiri

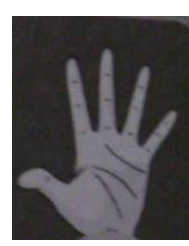

35

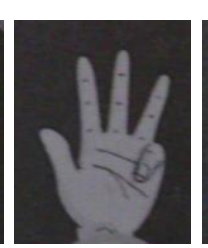

36

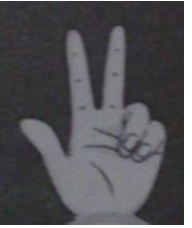

37

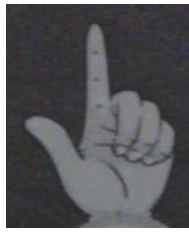

38

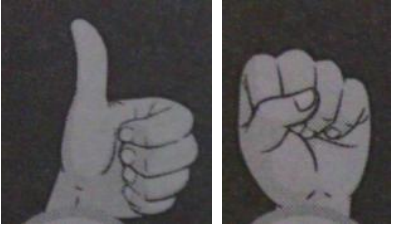

39

40

Kombinasi tangan kanan

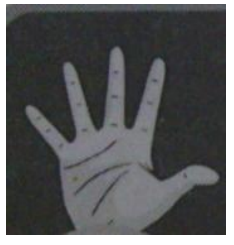

35

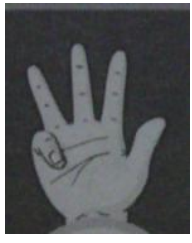

36

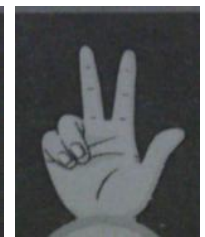

37

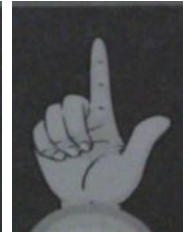

38

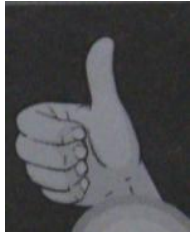

39

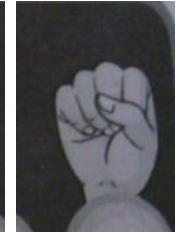

40

Kali $35-40=(120+4 \mathrm{~T})_{-}$B

$\mathrm{T}$ adalah jumlah jari yang telungkup

$\mathrm{B}$ adalah perkalian jari yang terbuka

Contoh

$37 \times 35=$ ?

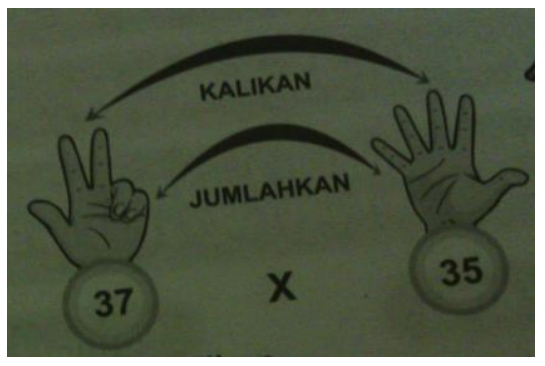

Jari kanan dan kiri terbuka kalikan, jari kanan dan kiri yang telungkup jumlahkan

$\mathrm{T}=$ jumlah jari yang telungkupnya $\quad=2+0=2$

$\mathrm{B}=$ perkalian jari yang terbuka $\quad=3 \times 5=15$

Sehingga : 37 x $35=(120+4 T) \_B$

$$
=(120+4 \times 2) \_15
$$




$$
\begin{aligned}
& =(120+8) \_15 \\
& =128 \_15 \\
& =(128+1) \_5 \\
& =1295
\end{aligned}
$$

\section{Perkalian kombinasi 41-45}

Kombinasi tangan kiri

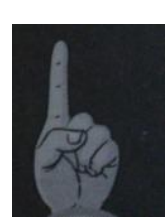

41

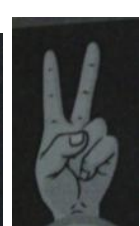

42

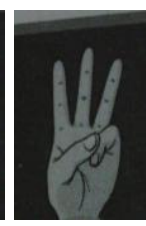

$43 \quad 44$

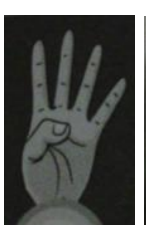

$44 \quad 45$

Kombinasi tangan kanan

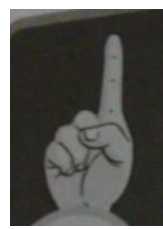

41

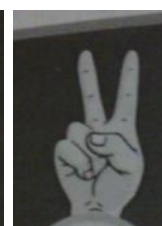

42

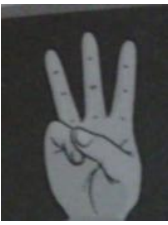

43

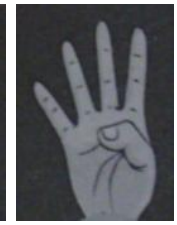

44

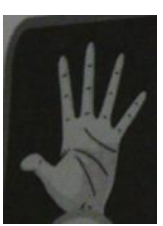

Kali 41-45 = 16_4J _ B

$\mathbf{J}$ adalah jumlah jari yang terbuka

$\mathrm{B}$ adalah perkalian jari yang terbuka

Contoh

$44 \times 42=$ ?

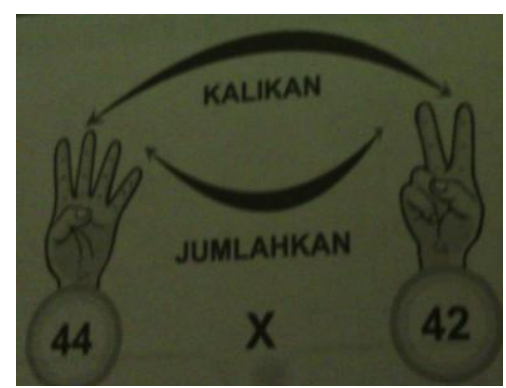

Jari kanan dan kiri terbuka kalikan, jari kanan dan kiri yang terbuka dijumlahkan

$\mathrm{J}=$ jumlah jari yang terbuka $=4+2=6$

$\mathrm{B}=$ perkalian jari yang terbuka $=4 \times 2=8$

Sehingga : 44 x $42=16 \_4 J \_B$

$$
\begin{aligned}
& =16 \_(4 \times 6) \_8 \\
& =16 \_24 \_8
\end{aligned}
$$




$$
\begin{aligned}
& =(16+2) \_4 \_8 \\
& =1848
\end{aligned}
$$

\section{Perkalian kombinasi 45-50}

Kombinasi tangan kiri

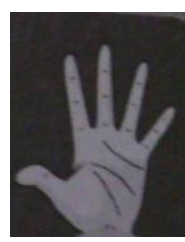

45

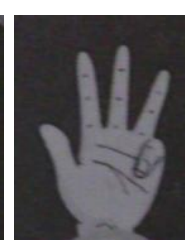

46

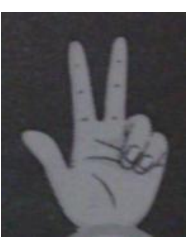

47

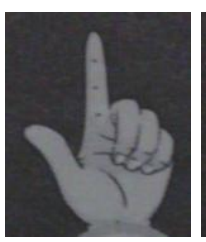

48

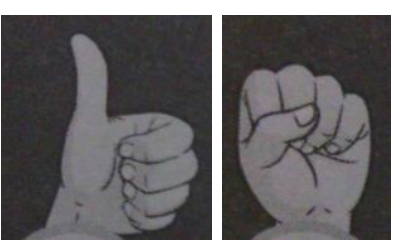

$49 \quad 50$

Kombinasi tangan kanan

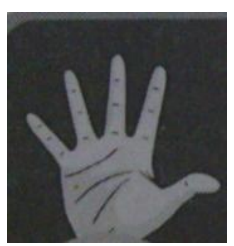

45

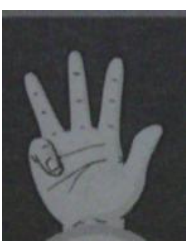

46

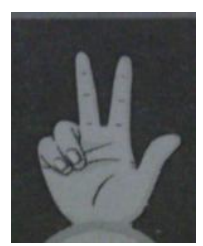

47

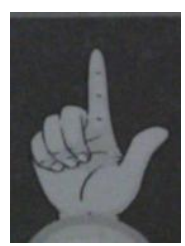

48

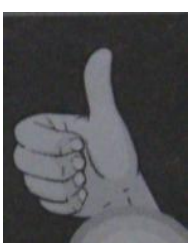

49

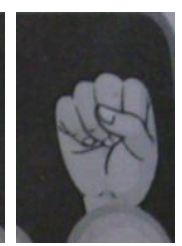

50

Kali $45-50=(200+5 \mathrm{~T}) \_$B

$\mathrm{T}$ adalah jumlah jari yang telungkup

$\mathrm{B}$ adalah perkalian jari yang terbuka

Contoh

$47 \times 45=$ ?

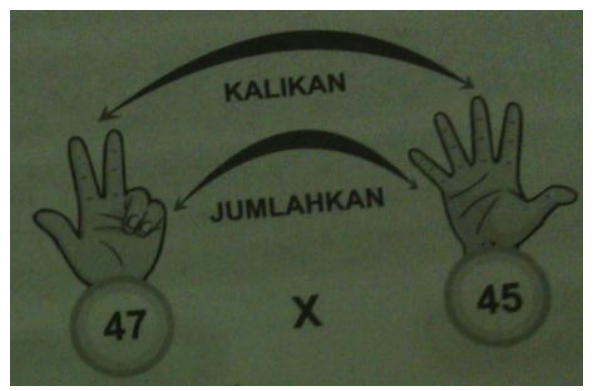

Jari kanan dan kiri terbuka kalikan, jari kanan dan kiri yang telungkup jumlahkan

$\mathrm{T}=$ jumlah jari yang telungkupnya $\quad=2+0=2$

$\mathrm{B}=$ perkalian jari yang terbuka $\quad=3 \times 5=15$

Sehingga : 47 x $45=(200+5 T) \_B$

$$
\begin{aligned}
& =(200+5 \times 2) \_15 \\
& =(200+10) \_15 \\
& =210 \_15
\end{aligned}
$$




$$
\begin{aligned}
& =(210+1) \_5 \\
& =2115
\end{aligned}
$$

\section{Perkalian kombinasi 51-55}

Kombinasi tangan kiri

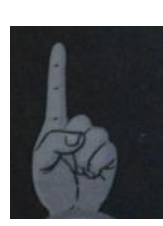

51

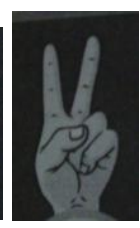

52

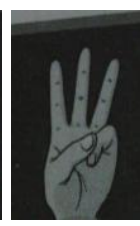

$53 \quad 54$

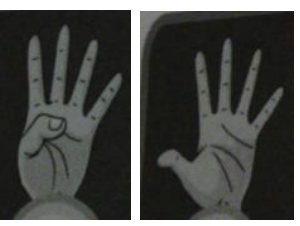

55

Kombinasi tangan kanan

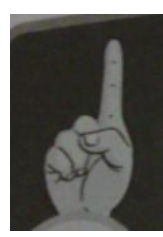

51

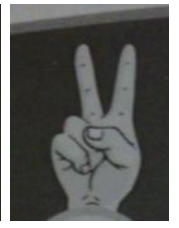

52

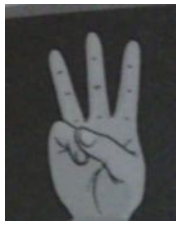

53

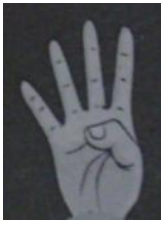

54

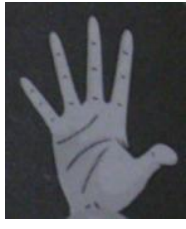

55

Kali 51-55=25_5J_B

$\mathrm{J}$ adalah jumlah jari yang terbuka

$\mathrm{B}$ adalah perkalian jari yang terbuka

Contoh

$54 \times 52=?$

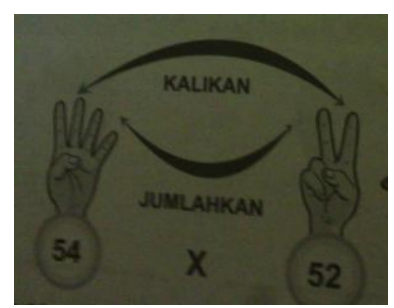

Jari kanan dan kiri terbuka kalikan, jari kanan dan kiri yang terbuka dijumlahkan

$\mathrm{J}=$ jumlah jari yang terbuka $\quad=4+2=6$

$\mathrm{B}=$ perkalian jari yang terbuka $=4 \times 2=8$

Sehingga : 54 x $52=25 \_5 \mathrm{~J} \_B$

$$
\begin{aligned}
= & 25 \_(5 \times 6) \_8 \\
& =25 \_30 \_8 \\
& =(25+3) \_0 \_8 \\
& =\mathbf{2 8 0 8}
\end{aligned}
$$




\section{Perkalian kombinasi 55-60}

Kombinasi tangan kiri

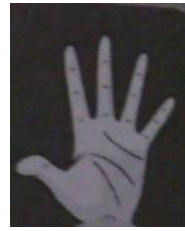

55

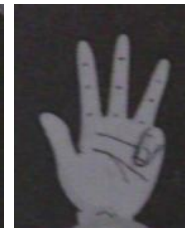

56

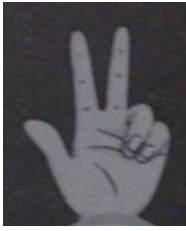

57

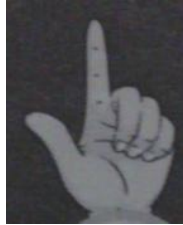

58

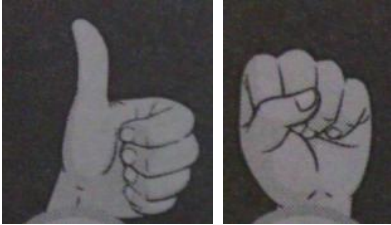

59

60

Kombinasi tangan kanan

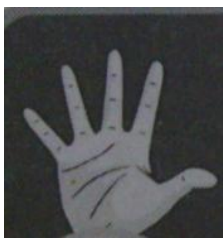

55

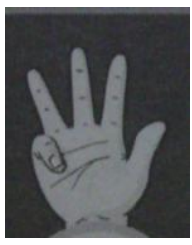

56

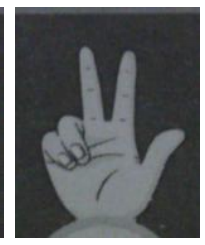

57

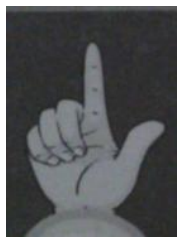

58

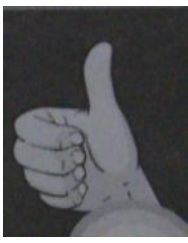

59

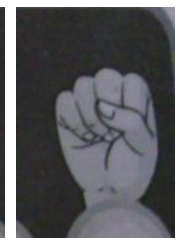

60

Kali $55-60=(300+6 \mathrm{~T})_{-}$B

$\mathrm{T}$ adalah jumlah jari yang telungkup

$\mathrm{B}$ adalah perkalian jari yang terbuka

Contoh

$57 \times 55=$ ?

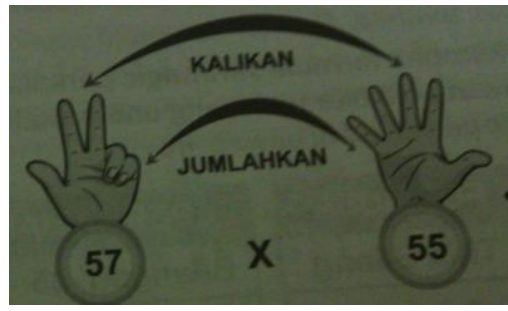

Jari kanan dan kiri terbuka kalikan, jari kanan dan kiri yang telungkup jumlahkan

$\mathrm{T}=$ jumlah jari yang telungkupnya $\quad=2+0=2$

$\mathrm{B}=$ perkalian jari yang terbuka $\quad=3 \times 5=15$

Sehingga : 57 x $55=(300+6 \mathrm{~T}) \_B$

$$
\begin{aligned}
& =(300+6 \times 2) \_15 \\
& =(300+12) \_15 \\
& =312 \_15 \\
& =(312+1) \_5 \\
& =3135
\end{aligned}
$$

Perkalian dengan 11 kombinasi diatas dapat disimpulkan bahwa: 
1. Setiap anak hanya menghafalkan kombinasi tangan kanan dan tangan kiri dari 09.

2. Untuk perkalian kombinasi 1-5 adalah titik temu antara dua jari.

3. Untuk perkalian kombinasi 11-15, 21-25, 31-35, 41-45, 51-55 yaitu
a. menghafal kombinasi jari kanan dan kiri angka 1-5
b. menjumlahan jari yang terbuka
c. perkalian jari yang terbuka
d. hasilnya adalah angka puluhan dikudratkan_(angka dikalikan dengan penjumlahan jari terbuka)_perkalian jari terbuka

4. Untuk perkalian kombinasi 5-10 adalah penjumlahan jeri telungkup_perkalian jari terbuka.

5. Untuk perkalian kombinasi 15-20, 25-30, 35-40, 45-50, 55-60 adalah
a. Menghafal kombinasi jari kanan dan kiri angka 0 dan 5-9
b. Menjumlahkan jari telungkup
c. Mengkalikan jari terbuka
d. Hasilnya (perkalian puluhan antara dua bilangan ditambah (angka puluhan terbesar dikalikan dengan penjumlahan jari telungkup))_perkalian jari terbuka




\section{KESIMPULAN}

Pembelajaran matematika dalam operasi hitung perkalian metode jarimagic membantu mempermudah anak untuk menghitung operasi perkalian dengan mudah, juga mengasah otak kanan anak dalam berfikir. 


\section{DAFTAR PUSTAKA}

Auliya, M. Fajar. 2012. Jarimagic Perkalian dan Pembagian. Jakarta: PT. Buku Seru

Bachtiar Soeseno. 2012. Buku Pintar memahami Psikologi Anak Didik. Yogjakarta: Pinang Merah Publisher.

Fazlurrachman, Haris. 2008. Monograf Bahan Ajar Gender. http://curhatpendidikan.blogspot.com/2008/07/monograf.html. (6-1-2009)

Muliawan, Jasa Ungguh. 2009. Tips Jitu Memilih Minan Positif dan Kreatif untuk Anak Anda. Yogjakarta: DIVA Press.

Muhsetyo, Gatot. 2009. Pembelajaran Matematika SD. Jakarta: Universitas Terbuka.

Yusuf, Suhendra. Perbandingan Gender dalam Prestasi Literasi Siswa Indonesia. http://www.uninus.ac.id/PDF/Suhendra\%20Yusuf\%20\%20Makalah\%20untuk\%2 0Jurnal\%20Uninus.pdf. (20-12-2008).

http://oediku.wordpress.com/2010/01/09/keuntungan-pengguna-otak-kananberbanggalah-jika-engkau-bukan-pengguna-otak-kiri/ ( 25 April 2013)

http://dammar-asihan.blogspot.com/2013/03/perbedaan-fungsi-otak-kanan-danotak.html\# (25 April 2013) 